\title{
Kesantunan imperatif guru bahasa Indonesia dalam interaksi kelas
}

\author{
Istiqomah Nurzafira', Nurhadi², Martutik3 \\ Pendidikan Bahasa Indonesia, Fakultas Sastra, Universitas Negeri Malang1,2,3 \\ 1Correspondence: isti.nurzafira.1802118@students.um.ac.id
}

\begin{abstract}
Abstrak
Kesantunan merupakan salah satu aspek yang perlu diperhatikan dalam berkomunikasi, termasuk interaksi antara guru dan siswa dalam proses belajar mengajar. Penelitian ini bertujuan mendeskripsikan bentuk kesantuan imperative oleh guru terhadap siswa dalam interaksi kelas. Metode yang digunakan adalah pendekatan kualitatif dengan jenis penelitian pragmatik. Data penelitian ini berupa tuturan guru Bahasa Indonesia MA Al-Irtiqo Malang yang mengandung kalimat kesantunan imperatif linguistik dan pragmatik. Sumber data adalah tuturan lisan guru Bahasa Indonesia di MA dalam proses pembelajaran di kelas. Teknik pengumpulan data yang digunakan penelitian ini adalah (1) teknik simak bebas libat cakap, (2) teknik rekam, dan (3) teknik catat. Teknik analisis data yang digunakan penelitian ini secara garis besar meliputi tiga langkah, yaitu (1) reduksi data, (2) penyajian data, dan (3) klasifikasi serta penarikan simpulan. Hasil penelitian ini guru menggunakan kesantunan linguistik imperatif dan kesantunan pragmatik imperatif. Kesantunan linguistik ditandai dengan ungkapan penanda kesantunan tolong, ayo, coba dan silakan. Kesantunan pragmatik dibagi menjadi dua, yaitu tuturan deklaratif dan tuturan interogatif. Tuturan pragmatik deklaratif yang digunakan guru antara lain suruhan, ajakan dan larangan, sedangkan tuturan pragmatik interogatif antara lain perintah dan larangan.
\end{abstract}

Kata kunci: guru, kesantunan, linguistik, pragmatik

\section{Pendahuluan}

Kesantunan berbahasa merupakan salah satu aspek yang sangat diperhitungkan oleh penutur dalam berkomunikasi dengan mitra tutur. Kesantunan ini dimaknai upaya pemilihan tuturan yang dilakukan oleh penutur guna komunikasi berjalan dengan lancar sebagaimana yang diharapkan. Lee (2016) menyatkan bahwa kesantunan dibentuk untuk meningkatkan, mempertahankan, atau melindungi wajah/citra diri mitra tutur. Menurut Rahmatiah (2011) seseorang berbahasa dan berperilaku santun sebenarnya lebih terhadap wujud aktualisasi diri sebagai bentuk menjaga kehormatan dan martabat. Oleh karena itu, penggunaan bahasa 
yang santun dapat menunjukan identitas individu yang bertutur.

Tuturan imperatif dalam berkomunikasi sangat sering ditemukan di kehidupan sosial. Mauri \& Sansò (2011) menyatakan bahwa tuturan tersebut merupakan bentuk verbal paling sederhana dalam berbahasa dan sangat sering digunakan dalam percakapan sehari-hari yang digunakan oleh penutur sebagai arahan terhadap mitra tutur. Tuturan imperatif dapat diujarkan secara langsung maupun tidak langsung. Menurut Ruytenbeek (2019), imperatif yang memiliki kode dari sikap penutur memberikan dampak permintaan secara tidak langsung yang berorientasi pada kinerja mitra tutur untuk menghasilkan sebuah tindakan. Prastio, dkk. (2019) menyatakan bahwa makna tersembunyi dibalik tuturan tidak langsung untuk menjaga kesopanan bahasa dalam mencapai niat yang ingin dicapai.

Guru merupakan pendamping atau orang tua siswa di sekolah. Pengaruh lingkungan di sekolah memiliki dampak yang sangat besar terhadap proses perkembangan sikap siswa. Dukuzumuremyi \& Siklander (2018) menyatakan bahwa guru memainkan peran kunci dalam proses pembelajaran yang bermanfaat terhadap siswa. Menurut Suciu (2014), guru sebagai pengirim informasi terhadap siswa memiliki otoritas yang mampu mengirim pesan meliputi tuturan verbal dan non verbal (agresivitas, tekanan, frekuensi) sehingga menimbulkan status superior. Rizal (2017) menyatakan bahwa guru di lingkungan sekolah berperan sebagai wahana dalam memberikan pendidikan terhadap siswa, selain itu juga membentuk karakter siswa. Terutama di dalam proses pembelajaran, guru wajib dapat dijadikan contoh yang baik bagi siswa guna perkembangan mental dan sikap.

Tuturan imperatif guru dapat ditemukan dalam proses pembelajaran. Tuturan tersebut di antaranya untuk melakukan pengaturan, penegasan, dan pendisiplinan. Furtak, dkk., (2018) menyatakan bahwa guru harus memiliki jenis pengetahuan mengenai kedisiplinan. Dalam menggunakan tuturan imperatif terhadap siswa, guru yang memiliki latar belakang pendidikan tinggi lazimnya mempunyai pengalaman dalam bertutur lisan yang baik dan benar. Faizah. dkk., (2018) menyatakan bahwa guru yang baik adalah guru yang menanamkan ilmunya kepada siswa agar pandai dalam berinteraksi.

Faktor penunjang keberhasilan pembelajaran yang dilaksanakan oleh guru di sekolah diantaranya, yaitu memiliki kompetensi dalam berinteraksi sosial. Kompetensi ini dapat dilihat dari bahasa guru yang santun. Menurut Dukuzumuremyi \& Siklander (2018), interaksi sosial dapat meliputi tuturan verbal, emosional, kinestetik untuk memahami makna dan merespons penutur sesuai yang ingin dikehendaki. Oleh karena itu, seorang guru harus memiliki pengetahuan mengenai cara berkomunikasi ketika memerintah siswanya agar pesan komunikasi yang ingin disampaikan tercapai serta tidak menimbulkan kesalahpahaman. Selain itu, pemahaman mengenai kaidah penggunaan kalimat memerintah juga berdampak bagi mitra tutur (siswa), yaitu merasa dihargai. Pramujiono \& Nurjati (2017); Rizal (2017) menyatakan bahwa wujud 
penggunaan bahasa santun secara nyata terealisasikan melalui tindak tutur secara lisan yang membuat siswa merasa nyaman dalam proses pembelajaran dan hal ini diharapkan juga dapat diimplikasikan kepada siswanya sehingga siswa mampu berbahasa yang santun.

Guru bahasa Indonesia dituntut memiliki empat keterampilan berbahasa, yaitu menyimak, berbicara, membaca, dan menulis. Empat keterampilan berbahasa tersebut yang membedakan guru bahasa Indonesia dinilai memiliki kualitas keterampilan berbahasa lebih baik dan memiliki tingkat evaluasi yang lebih tinggi ketika bertutur di dalam proses pembelajaran dibandingkan dengan guru mata pelajaran lain. Iskandarwassid (2013, hlm. 240) menyatakan bahwa dalam pengajaran bahasa Indonesia penutur bahasa Indonesia (guru) seharusnya memiliki tingkat evaluasi yang tinggi karena bahasa Indonesia sebagai bahasa ibu atau kedua. Oleh karena itu, kemampuan mengevaluasi tuturan guru bahasa Indonesia dituntut jauh lebih tinggi karena pada dasarnya bahasa Indonesia sudah dikenal atau diketahui oleh siswa sebagai bahasa pertama atau keduanya.

Kesantunan berbahasa seorang guru dalam komunikasi banyak terlihat dalam proses interaksi belajar mengajar. Pada proses belajar mengajar, komunikasi yang berlangsung ialah komunikasi dua arah antara guru dan siswa. Proses komunikasi ini secara tidak langsung menuntut nilai-nilai kesantunan berbahasa guru dalam interaksi kelas. Hal ini karena guru dianggap sebagai contoh ideal bagi siswa, termasuk dalam kesantunan berbahasa. Menurut Nunn (2006) teori komunikasi seorang guru bahasa tidak hanya digunakan untuk konten pembelajaran, tetapi juga dapat dimanfaatkan ketika proses pembelajaran bahasa dengan memperhatikan pemahaman guru mengenai teori kesantunan.

Sebagai landasan penelitian ini, Lakoff (dalam Rahardi, 2009, hlm. 95) menyatakan bahwa kesantunan sebuah tuturan akan terjadi manakala terdapat opsi-opsi atau alternatif-alternatif yang harus dipilih oleh mitra tutur. Pada kesantunan bertutur ada sejumlah pakar yang mengajukan teori kesantunan diantaranya Brown dan Levinson (1978), Leech (1983) dan Rahardi (2005). Pada penelitian ini penulis merujuk pada teori kesantunan Rahardi, karena fokus pada penelitian ini yaitu kesantunan imperatif dilihat dari kesantunan linguistik imperatif dan kesantunan pragmatik imperatif.

Kesantunan linguistik dapat ditandai dengan tuturan yang menggunakan ungkapan penanda kesantunan. Rahardi (2005, hlm. 125-134) menyatakan bahwa penanda kesantunan meliputi tolong, mohon, silakan, mari, ayo, biar, coba, harap, hendaknya, hendaklah, -lah, sudi kiranya, sudilah kiranya, sudi apalah kiranya. Kesantunan pragmatik merupakan kesantunan yang dituturkan secara tidak langsung. Artinya, apa yang diharapkan terjadi tidak sesuai dengan apa yang diungkapkan. Kesantunan pragmatik dibagi menjadi dua, yaitu kesantunan pragmatik tuturan deklaratif dan tuturan interogatif. Kesantunan dengan menggunakan tuturan deklaratif dapat dilakukan sebagai ekspresi 
kesantunan pragmatik berupa, suruhan, ajakan, permohonan, persilaan, dan larangan. Berbeda dengan kesantunan tuturan deklaratif, kesantunan dengan menggunakan tuturan interogatif dituturkan sebagai ekspresi dari kesantunan pragmatik berupa, perintah, ajakan, permohonan, persilaan, dan larangan. Kesantunan berbahasa oleh penutur diharapkan dapat memperlancar komunikasi terhadap mitra tuturnya. Begitu juga dengan komunikasi yang terjadi pada proses belajar mengajar, yaitu antara guru dan siswa sebagaimana disebut sebelumnya.

Penelitian mengenai kesantunan sebelumnya sudah pernah dilakukan oleh Ikawati (2010) dengan judul "kesantunan menolak dalam interaksi percakapan keluarga angkatan darat di kompleks Asmil Yonif 514 Kabupaten Bondowoso: Kajian etnografi komunikasi”. Hasil penelitian tersebut berupa deskripsi wujud kesantunan menolak, fungsi kesantunan, dan strategi kesantunan. Persamaan penelitian yang dilakukan oleh Ikawati adalah samasama meneliti kesantunan dengan menggunakan kajian etnografi komunikasi. Perbedaan penelitian ini dengan penelitian sebelumnya terletak pada fokus penelitian. Kesantunan pada penelitian sebelumnya berfokus pada tuturan yang menunjukkan makna penolakan, sedangkan penelitian ini berfokus pada makna perintah.

Berdasarkan uraian di atas, kesantunan bahasa lisan guru merupakan salah satu sarana pembentukan karakter siswa demi membangun pondasi peradaban bangsa yang sejahtera dan berakhlak mulia. Dengan demikian, hal tersebut menjadi dasar bahwa betapa pentingnya melakukan penelitian ini. Hasil penelitian ini dapat dijadikan sebagai implementasi konsep kesantunan berbahasa dan dapat menjadi rujukan praktis di sekolah.

\section{Metode}

Penelitian ini menggunakan metode pendekatan kualitatif. Adapun pendekatan ini mendeskripsikan membuat gambaran secara faktual mengenai data tuturan imperatif guru bahasa Indonesia. Jenis penelitian ini adalah pragmatik. Selain memahami tuturan oleh mitra tutur, komunikasi sering memiliki makna tersembunyi dibalik sebuah tuturan yang dapat dilihat dari konteks tuturan tersebut.

Data penelitian ini berupa tuturan guru bahasa Indonesia MA Al-Irtiqo Malang, yang mengandung kalimat kesantunan imperatif linguistik dan pragmatik. Sumber data berupa tuturan lisan guru Bahasa Indonesia di SMA dalam proses pembelajaran di kelas. Penelitian ini meneliti seorang guru bahasa Indonesia kelas X 11 yang bernama Risnawati, S.Pd. berusia 22 tahun. Peneliti melaksanakan penelitian pada hari Jumat tanggal 23 November 2018 pukul 10.15- 11.45 WIB.

Instrumen utama penelitian ini adalah peneliti sendiri sebagai instrumen inti atau insani (human instrument). Instrumen inti dalam penelitian ini dengan 
cara membekali diri dengan pemahaman yang mendalam mengenai teoritis dan metodologis. Di samping itu, terdapat instrumen alat bantu saat proses penelitian seperti smarthphone, catatan lapangan, serta instrumen pelengkap saat proses penelitian, yakni panduan pengumpulan data dan analisis data untuk mengkategorikan kesantunan imperatif guru.

Teknik pengumpulan data yang digunakan penelitian ini adalah (1) teknik simak bebas libat cakap, pendengar hanya sebagai pengamat dan memperhatikan tuturan mitra tutur sehingga tidak bertindak sebagai pembicara yang berhadapan dengan mitra tutur, (2) teknik rekam, pada teknik ini membantu untuk menganalisis data. Alat rekam yang digunakan adalah smartphone dengan aplikasi perekaman suara, dan (3) teknik catat. Pengumpulan data biasanya menghasilkan catatan tertulis sangat mengenai percakapan yang berisi penggalan data yang jamak nantinya dipilah-pilah dan dianalisis.

Teknik analisis data yang digunakan penelitian ini secara garis besar meliputi tiga langkah, yaitu (1) reduksi data, mentranskripsi data yang terjadi di lapangan sesuai dengan isi rekaman, kemudian data berupa tuturan yang tidak memiliki kalimat imperatif direduksi atau dihilangkan, (2) penyajian data, mengidentifikasi tuturan kalimat imperatif yang telah diperoleh, dan (3) klasifikasi serta penarikan simpulan, data yang diperoleh diklasifikasikan sesuai indikator setelah itu diambil sebuah simpulan untuk menjelaskan kesantunan imperatif guru bahasa Indonesia di MA.

\section{Hasil}

Hasil penelitian menunjukkan bahwa guru bahasa Indonesia di MA Al-Irtiqo menggunakan kesantunan linguistik imperatif dan kesantunan pragmatik imperatif. Kesantunan linguistik imperatif yang muncul yaitu tolong, ayo, coba, silakan. Kesantunan pragmatik imperatif dibagi menjadi dua, yaitu kesantunan pragmatik tuturan deklaratif dan kesantunan pragmatik tuturan interogatif. Tuturan deklaratif diantranya muncul kesantunan suruhan, ajakan, persilaan dan larangan, sedangkan tuturan interogatif sebagai ekspresi kesantunan pragmatik perintah, larangan.

Tabel 1. Hasil kesantunan linguistik imperatif guru bahasa Indonesia MA Al-Irtiqo

\begin{tabular}{lc}
\hline Kesantunan linguistik imperatif & Jumlah penggunaan \\
\hline Tolong & 4 \\
Ayo & 8 \\
Coba & 10 \\
Silakan & 3 \\
\hline Jumlah & 25 \\
\hline
\end{tabular}


Tabel 2 Hasil kesantunan pragmatik imperatif guru bahasa Indonesia MA Al-Irtiqo

\begin{tabular}{ll}
\hline \multicolumn{2}{c}{ Kesantunan pragmatik imperatif } \\
\hline Kesantunan pragmatik tuturan deklaratif & Jumlah penggunaan \\
\hline Suruhan & 3 \\
Ajakan & 3 \\
Larangan & 1 \\
\hline Kesantunan pragmatik tuturan interogatif & Jumlah penggunaan \\
\hline Perintah & 5 \\
Larangan & 4 \\
\hline Jumlah & 16 \\
\hline
\end{tabular}

\section{Pembahasan}

\section{Kesantunan linguistik imperatif}

\section{Kesantunan Tolong}

(Sebelum memulai proses pembelajaran, guru memasuki ruangan kelas dan melihat sampah menumpuk di dalam kotak sampah yang ada di dalam kelas. Guru meminta siswa untuk membuang sampah ke luar).

Guru : Tolong dong, Nak dibuang sampahnya! Gak enak nanti baunya.

Konteks Tuturan:

Tuturan ini disampaikan guru ketika melihat ke tempat sampah yang penuh oleh sampah-sampah plastik dan kertas.

Tuturan guru diungkapkan sebelum proses pembelajaran dimulai. Ia melihat tempat sampah yang ada di kelas sangat penuh oleh sampah kertas maupun sampah plastik bekas pembungkus jajanan para siswa yang dibuang ke dalam tempat sampah tersebut. Guru meminta salah satu siswa untuk segera membuang sampah itu ke keluar kelas dengan tuturan "Tolong dong, Nak dibuang sampahnya! Gak enak nanti baunya".

Berdasarkan analisis, tuturan ini termasuk kesantunan linguistik imperatif karena ditandai dengan munculnya salah satu ungkapan penanda kesantunan yaitu tolong pada awal tuturan. Secara teori, adanya ungkapan tolong dapat memperhalus maksud guru yang memerintah siswa untuk membuang sampah dibandingkan dengan tuturan tanpa menggunakan ungkapan tersebut seperti "Nak, dibuang sampahnya! Gak enak nanti baunya".

Tuturan guru tersebut berupa kalimat imperatif. Aarts dan Aarts (dalam Worotikan, 2015) menyebutkan bahwa kalimat perintah mengandung sebuah kata kerja dalam imperative mood (mengekspresikan dengan sebuah perintah secara langsung kepada seseorang atau beberapa orang). Hal ini terlihat pada 
tuturan Tolong dong, Nak dibuang sampahnya! Gak enak nanti baunya. Tuturan di atas lebih terlihat kesantunannya karena kata tolong berada di depan kalimat. Rahardi (1999) menyatakan bahwa kesantunan linguistik tuturan imperatif mencakup urutan tutur, urutan sangat menentukan penilaian seseorang terhadap perilaku kesantunan orang tersebut.

Tuturan di atas juga termasuk kalimat imperatif tanpa subjek. Quirk dan Greenbaum (dalam Novita, 2016) berpendapat bentuk kalimat imperatif tanpa subjek yaitu kata kerja tidak menggunakan subjek dan langsung menggunakan kata kerja bentuk dasar.

\section{Kesantunan Ayo}

Guru : Nak, Ibu punya contoh puisi "Rembulan Malam". Kemarin Lia dapet juara lomba ya. Ayo Lia, bantu ibu membacakan puisi di depan teman-temanmu.

Konteks Tuturan:

(Guru memberi materi mengenai puisi, guru meminta salah satu siswa untuk memberi contoh membaca puisi di depan kelas).

Tuturan guru diujarkan ketika kegiatan inti dalam pembelajaran. Guru memberi perintah kepada siswa umtuk membacakan puisi di depan kelas. Tuturan ini disampaikan guru dengan penyampaian apresiasi terlebih dahulu setelah itu memerintah siswa untuk membacakan puisi di depan kelas. Menurut Hanafi, dkk. (2014) berkomunikasi dengan bahasa guna mencapai tujuan, kejelasan berbicara diperlukan secara berurutan sehingga pendengar dapat menerima atau memahami makna yang dimaksudkan.

Berdasarkan analisis, tuturan ini termasuk kesantunan linguistik imperatif karena terdapat ungkapan penanda kesantunan ayo pada tuturan. Secara teori menurut Rahardi (2005, hlm. 125), adanya ungkapan ayo ini dapat memperhalus maksud tuturan itu karena jika tidak menggunakan ungkapan ayo memiliki perintah yang kasar. Dibuktikan dengan kalimat berikut "Ayo Lia, bantu ibu membacakan puisi di depan teman-temanmu."

Dengan adanya ungkapan penanda kesantunan ayo maka tuturan tersebut dapat memiliki makna ajakan. Makna ajakan lebih santun dibandingkan dengan tuturan yang bermakna perintah. Pembicara mampu memberikan contoh yang baik kepada siswa mereka dengan mempertimbangkan pilihan kata, cara menyajikannya, dan seterusnya (Hanafi, dkk., 2014).

\section{Kesantunan Coba}

Guru : Anak-anak, udah selesai baca 3 puisinya? Sekarang coba kalian temukan kata-kata di dalam puisi tersebut yang mengandung makna konotasi!

Konteks Tuturan:

Tuturan ini diungkapkan guru untuk memerintah siswa menemukan konotasi di 
dalam contoh 3 puisi di dalam buku teks

Tuturan guru tersebut diucapkan saat proses pembelajaran berlangsung. Guru memerintah atau memberikan siswa kesempatan untuk menemukan makna konotasi di dalam teks puisi. Tuturan ini menggunakan ungkapan penanda kesantunan coba dengan intonasi nada yang tidak tinggi. DePaulo dan Friedman (dalam Laptante dan Nalini, 2003) menyatakan penggunaan intonasi nada yang tidak tinggi akan memberikan perhatian yang lebih sebagai wujud kesantunan.

Rahardi (2005, hlm. 125) menyatakan bahwa adanya ungkapan coba dapat memperhalus maksud tuturan dibandingkan dengan tuturan yang tidak menggunakan ungkapan penanda tersebut. Dapat dibuktikan pada kalimat berikut "Sekarang kalian temukan kata-kata di dalam puisi tersebut yang mengandung makna konotasi!" Tuturan ini terdengar tidak halus karena guru tidak menggunakan ungkapan kesantunan pada tuturan tersebut. Oleh karena itu, tuturan ini termasuk kesantunan linguistik imperatif. Dengan menggunakan bentuk yang demikian (coba) seolah-olah mitra tutur diperlakukan sebagai orang yang sejajar dengan si penutur kendatipun pada kenyataannya peringkat kedudukan (rank rating) di antara keduanya berbeda (Rahardi, 1999).

\section{Kesantunan Silakan}

(Guru memulai pembelajan di kelas. Pada hari itu guru memberi materi mengenai puisi)

Guru : Silakan buka buku kalian halaman 25. Silakan kalian baca dalam hati terlebih dahulu, setelah itu Ibu beri kesempatan kalian untuk membacakan di depan kelas.

Konteks Tuturan:

Guru mempersilakan siswa untuk membuka buka mata pelajaran Bahasa Indonesia.

Tuturan guru diucapkan ketika dalam proses pembelajaran. Tuturan ini disampaikan guru untuk mempersilakan siswa membuka halaman tersebut dengan tujuan agar siswa membaca teks yang ada di halaman 25. Guru memperhatikan kesantunan di awal kalimat dalam tuturannya dengan menggunakan kata silakan. Silakan yang dilekatkan di awal tuturan imperatif dapat berfungsi sebagai penghalus tuturan maupun penentu kesantunan linguistik tuturan imperatif itu (Rahardi, 1999).

Berdasarkan analisis yang dilakukan, tuturan ini termasuk kesantunan linguisitik imperatif. Hal ini terlihat dari adanya kata silakan yang sesuai dengan teori Rahardi yang mengatakan bahwa kata tersebut sebagai ungkapan penanda kesantunan untuk memperhalus maksud tuturan perintah. Dikatakan demikian jika dibandingkan dengan tuturan yang disampaikan tanpa menggunakan 
ungkapan silakan, tuturan tersebut menjadi tidak santun karena maksud memerintahnya terdengar lebih jelas.

\section{Kesantunan pragmatik imperatif}

\section{Kesantunan pragmatik tuturan deklaratif}

\section{Tuturan deklaratif suruhan}

(Guru memasuki ruangan untuk memulai pembelajaran. Mayoritas siswa sedang menulis sesuatu di buku tulis).

Guru : (Menghampiri salah satu murid yang duduk di bangku depan) Mengerjakan apa nak?

Murid : (Berhenti menulis dan memasukan bukunya ke dalam tas)

Guru : Sekarang kita mulai belajar mata pelajaran bahasa Indonesia. Taruh dulu penanya di meja. Yang masih mengerjakan tugas, bisa dilanjutkan nanti, istirahat.

Tuturan guru diucapkan sebelum pembelajaran dimulai. Guru melihat mayoritas siswa di kelas sedang menulis sesuatu di buku tulis mereka. Guru menyampaikan kalimat "Yang masih mengerjakan tugas, bisa dilanjutkan nanti, istirahat" dengan maksud memerintah siswa untuk memperhatikan guru yang akan memulai proses pembelajaran.

Siswa harus mempunyai kapasitas kognitif yang canggih untuk memahami tuturan guru yang memerintah siswa untuk menutup bukunya daripada guru menggunakan kalimat imperatif langsung kepada siswa, misalnya. "Tutup buku kalian!" Brinck (2004) menyatakan bahwa tuturan deklaratif suruhan lebih banyak membutuhkan kapasitas kognitif, di dalam konteks ini yaitu siswa. Tuturan yang tidak dinyatakan secara langsung ini dapat memperhalus maksud tuturan. Oleh karena itu, tuturan ini termasuk kesantunan pragmatik imperatif karena terdapat kalimat deklaratif yang menyatakan makna pragmatik imperatif suruhan pada tuturan tersebut.

\section{Tuturan deklaratif ajakan}

Guru : Tadi Ibu sudah beritahu perbedaan karakteristik dari puisi kontemporer dan moderen, untuk contohnya kita lanjutkan di pertemuan yang akan datang ya! karena waktunya telah habis.

Konteks Tuturan:

Durasi proses pembelajaran telah selesai ditandai dengan bel yang berbunyi. Guru memberikan tuturan tersebut untuk menutup proses pembelakaran.

Tuturan ini disampaikan guru karena durasi pembelajaran telah berakhir. Guru mengajak siswa untuk melakukan tindak lanjut mengenai puisi, membahas masing-masing contoh puisi kontemporer dan moderen pada pertemuan yang 
akan datang (pekan depan). Guru menyampaikan maksud ajakannya dengan menggunakan kalimat deklaratif, "untuk contohnya kita lanjutkan di pertemuan yang akan datang ya! karena waktunya telah habis."

Tuturan ini bermakna ajakan kepada siswa. Guru menyampaikannya secara tidak langsung kepada siswa dan tuturan yang bermaksud perintah ini terdengar lebih santun. Brown \& Levinson (dalam Rica \& Yapılarında, 2015) menyatakan bahwa inheren pada tuturan mengajak memiliki maksud yang sama tetapi pelafalan ajakan pada tuturan pragmatik berbeda, dengan menggunakan kalimat yang lebih halus. Jika dibandingkan dengan tuturan yang tanpa menggunakan kalimat deklaratif menjadi "besok kita lanjutkan!" maka tuturan ini akan terdengar menjadi tidak santun.

\section{Tuturan deklaratif larangan}

(Beberapa siswa belum bisa memahami isi teks puisi karena menggunakan kata kiasan atau konotasi)

Guru : Nak, lihat kesatuan kalimatnya. Kalau kalian mengartikan satu-satu kata yang konotasi, makna keseluruhan kalimat nanti sulit dapetnya

Konteks Tuturan:

Tuturan ini disampaikan guru untuk menjelaskan kepada siswa cara memahami isi teks puisi.

Tuturan guru diucapkan di bagian kegiatan inti dalam pembelajaran. Tuturan ini disampaikan untuk memudahkan siswa dalam memahami isi teks puisi. Hal ini berupa nasihat untuk siswa dalam memahami isi teks agar tidak mengartikan kata per kata yang bermakna konotasi, melainkan konteks kalimat.

Guru menggunakan kesantunan pragmatik imperatif berupa tuturan deklaratif larangan. Perintah larangan guru dalam tuturan tersebut menggunakan kalimat deklaratif secara tidak langsung. Dibandingkan dengan tuturan yang tanpa menggunakan kalimat deklaratif maka maksud larangan tersebut akan sangat jelas dan terdengar tidak santun. Kalimat larangan biasanya ditandai oleh kata jangan. Musbikin (dalam Gunadi, 2017) menjelaskan jangan memberi perintah atau larangan dengan kata jangan. Anak akan semakin melakukan yang sebaliknya dilarang.

Tuturan deklaratif larangan membuat perintah kepada sasaran (murid) lebih santun. Jika guru mengujarkan "Jangan mengartikan kata satu-satu" kesantunan yang dipakai oleh guru menurun. Anggraini (2005) menyatakan bahwa ciri ketidaklangsungan tuturan imperatif sangat jelas, tuturan memiliki kesantunan lebih tinggi karena tidak mengandung konstruksi larangan secara langsung. 


\section{Kesantunan imperatif tuturan interogatif}

\section{Tuturan interogatif perintah}

Pembelajaran bahasa Indonesia dimulai ketika istirahat pertama selesai. Ada beberapa siswa yang masih makan dan minum di dalam kelas setelah bel berbunyi yang menandakan pembelajaran akan dimulai.

Guru : Belum selesai ya nak makannya?

Konteks Tuturan:

Tuturan guru disampaikan karena beberapa siswa di dalam kelas masih makan dan minum

Tuturan guru diujarkan pada bagian kegiatan awal proses pembelajaran. Guru harus memiliki keterampilan pada proses awal pembelajaran. Azis (2016) menyatakan bahwa membuka pelajaran adalah kegiatan yang dilakukan oleh guru untuk menciptakan suasana siap mental dan menimbulkan perhatian siswa agar terpusat pada hal-hal yang akan dipelajari. Kalimat interogatif yang digunakan oleh guru yang disampaikan di awal pembelajaran, dengan tujuan untuk memerintah siswa yang sedang makan untuk berhenti, karena proses pembelajaran segera dimulai.

Tuturan ini termasuk kesantunan pragmatik imperatif karena terdapat kesantunan dalam menyampaikan maksud perintah guru tersebut, yakni dengan menggunakan kalimat interogatif. Dikatakan demikian karena jika tuturan yang tanpa menggunakan kalimat tanya untuk menyatakan maksud perintah tersebut maka akan menjadi tidak santun.

Kalimat interogatif tidak hanya berdasarkan isi dan jawaban. Jika orang ingin mengetahui jawaban atas suatu masalah atau situasi, maka mereka meminta dan menggunakan kalimat tanya (Moeliono \& Dardjowidjoyo: 1988, hlm. 288). Kalimat interogatif guru untuk siswa di dalam konteks ini tidak memerlukan jawaban, melainkan harapan penutur agar mitra tutur melakukan tindakan. Lindawati (2016) menyatakan bahwa tuturan interogatif yang dituturkan oleh seseorang harus melihat konteks atau latar belakang tuturan tersebut diujarkan.

Guru memerintahkan siswa secara tidak langsung menggunakan kalimat tanya bagi siswa yang masih makan dan minum. Jika guru memerintah siswa untuk berhenti makan menggunakan tuturan langsung, hal itu dapat membuat siswa terpojok. Guru menggunakan tuturan berupa pertanyaan untuk memperhalus tuturan perintahnya.

\section{Tuturan interogatif larangan}

(Guru beralih ke sub bab selanjutnya mengenai jenis-jenis puisi)

Guru : Sekarang kita buka halaman 28! Kok yang dipojok ngobrol terus ya dari tadi? 
Konteks Tuturan:

Tuturan ini disampaikan saat kegiatan inti pembelajaran berlangsung di dalam kelas. Guru melihat muridnya sedang mengobrol saat guru memberi penjelasan di dalam kelas.

Guru memerintah siswa untuk membaca buku teks bahasa Indonesia halaman 28. Ketika guru memperhatikan murid-muridnya, ia melihat dua orang yang duduk bersebelahan selalu mengobrol. Guru menegur siswa tersebut, berikut tuturannya "Kok yang dipojok ngobrol terus ya daritadi?"

Penggunaan tuturan interogatif larangan oleh guru ketika sedang menegur siswanya "Kok yang dipojok ngobrol terus ya daritadi?" Tuturan guru diucapkan di dalam kegiatan inti pembelajaran guna mendisiplinkan siswa agar tidak berdiskusi ketika orang lain sedang berbicara. Sudjalil \& Mujioanto (2017) menyatakan bahwa strategi tuturan imperatif yang digunakan untuk menanamkan nilai-nilai karakter (disiplin) pada kegiatan inti ini adalah strategi langsung dan kesopanan positif. Larangan tersebut disampaikan secara tidak langsung kepada siswa dengan menggunakan kalimat interogatif. Menurut Kridalaksana (2011, hlm. 140), larangan merupakan makna ujaran yang bersifat melarang, diungkapkan dengan berbagai bentuk imperatif negatif atau dengan frase ingkar. Tuturan interogatif yang digunakan oleh guru dapat memperhalus maksud larangannya.

\section{Kesimpulan}

Berdasarkan penelitian ini, kesantunan imperatif yang digunakan oleh guru mata pelajaran bahasa Indonesia di kelas X berupa kesantunan linguistik imperatif dan kesantunan pragmatik imperatif. Kesantunan imperatif guru bahasa Indonesia di dalam kesantunan linguistik ditandai dengan ungkapan penanda kesantunan, yaitu tolong, coba, ayo, silakan. Kesantunan coba merupakan kesantunan yang dominan, sedangkan kesantunan silakan merupakan paling sedikit yang digunakan oleh guru. Kesantunan pragmatik imperatif guru bahasa Indonesia di kelas X, yaitu kesantunan bentuk tuturan deklaratif dan interogatif. Kesantunan pragmatik deklaratif yang ditemukan dalam penelitian ini, yaitu suruhan, ajakan, dan larangan. Adapun kesantunan pragmatik interogatif yang ditemukan dalam penelitian ini, yaitu perintah dan larangan.

Bagi pembaca, penulis berharap temuan ini dapat dijadikan bahan untuk menambah wawasan mengenai kesantunan imperatif yang dapat diaplikasikan di dalam tuturannya. Guru dapat memanfaatkan penelitian ini sebagai pengetahuan mengenai pengaruh kesantunan bagi murid dan membuat hubungan antara guru dan murid tidak terjadi kesalahpahaman. Bagi siswa, hasil penelitian ini dapat dijadikan contoh tuturan sebagai bahan pertimbangan kalimat yang akan digunakan untuk memerintah orang lain. Peneliti selanjutnya disarankan dapat meneliti kajian kesantunan berupa dampak tuturan tersebut. 


\section{Daftar rujukan}

Anggraini, B. (2005). Faktor-faktor penanda kesantunan tuturan imperatif dalam bahasa Jawa dialek Surabaya: Analisis pragmatik. Jurnal Humaniora. 17 (1), 67-77.

Azis, Asria. (2016). Pengaruh Keterampilan Membuka Pelajaran Terhadap Motivasi Siswa Dalam Belajar Bahasa Indonesia Sekolah Dasar. Journal of EST. 2 (2), 65-73. Dari https://media.neliti.com.

Brinck, I. (2004). The pragmatics of imperative and declarative pointing. LAVOISIER Cognitive Science Quarterly. 3 (4). 429-446.

Dukuzumuremyi, S., \& Siklander, P. (2018). Interactions Between Pupils and their Teacher in Collaborative and Technology-Enhanced Learning Settings in the Inclusive Classroom. Teaching and Teacher Education, 76, 165-174. https://doi.org/10.1016/j.tate.2018.08.010

Faizah, Dini; Utomo, Padi; Arifin, M. (2018). Analisis Pertanyaan Guru dan Siswa dalam Proses Pembelajaran Bahasa Indonesia di Kelas VII SMP Negeri 4 Kota Bengkulu. Jurnal Ilmiah Korpus, 2(3), 253-261. https://doi.org/10.1017/CBO9781107415324.004

Furtak, E. M., Bakeman, R., \& Buell, J. Y. (2018). Developing Knowledge-inAction with a Learning Progression: Sequential Analysis of Teachers ' Questions and Responses to Student Ideas. Teaching and Teacher Education. https://doi.org/10.1016/j.tate.2018.06.001

Gunadi, A. A. (2017). Pengaruh lingkungan sosial terhadap imajinasi anak. Jurnal Refleksi Edukatika. 7 (2), 95-101.

Hanafi, M., Lukman. \& Maknun, T. (2014). The representation of imperative politeness in academic discourse at STKIP Muhammadiyah Sidenreng Rappang (Sociopragmatic Study). International Journal of Enhanced Research in Science Technology \& Engineering. 3 (6), 87-90.

Ikawati, N. A. (2010). Kesantunan Menolak dalam Interaksi Percakapan Keluarga Angkatan Darat di Kompleks Asmil Yonif 514 Kabupaten Bondowoso Kajian Etnografi Komunikasi. Malang: Universitas Negeri Malang.

Iskandarwassid \& Sunendar, D. 2013. Strategi Pembelajaran Bahasa. Bandung: PT Remaja Rosdakarya.

Kridalaksana, Harimurti. (2011). Kamus linguistik. Jakarta: PT Gramedia Pustaka Utama.

Laptante, D. \& Ambady, N. (2003). On how things are said voice tone, voice intensity, verbal content, and perceptions of politeness. Journal of Language and Social Psychology. 22 (4), 434-441.

Lindawati. (2016). Fungsi Tutur Kalimat Tanya Bahasa Indonesia. Litera. 11 (2).

Lee, E. L. (2016). Language and Culture Language and Culture. https://doi.org/10.1093/acrefore/9780190228613.013.26

Mauri, C., \& Sansò, A. (2011). How Directive Constructions Emerge: Grammaticalization, Constructionalization, Cooptation. Journal of Pragmatics, 43 (14), 3489-3521. https://doi.org/10.1016/j.pragma.2011.08.001

Moeliono, A. M \& Dardjowidjoyo, S. (1988). Tata bahasa baku bahasa Indonesia. Jakarta: Balai Pustaka. 
Novita, W. (2016). Kalimat imperatif dalamm film SPY karya Paul Feig. Jurnal Elektronik Fakultas Sastra Universitas Sam Ratulangi. 4 (5), 1-14.

Nunn, R. (2006). The pragmatics of cooperation and relevance for teaching and learning. The Linguistics Journal. 1 (1), 5-16.

Pramujiono, A. \& Nurjati, N. (2017). Guru sebagai Model Kesantunan Berbahasa dalam Interaksi Instruksional di Sekolah Dasar. Mimbar Pendidikan. 2(2).

Prastio, B., Ibrahim, A. S., \& Susanto, G. (2019). Conversation Implicature in Interrogative Utterance of The Discourse of E-Commerce Business Advertisement. Journal Pendidikan:Teori, Penelitian, Dan Pendidikan, 906-911.

Rahardi, K. (1999). Imperatif dalam bahasa Indonesia: Penanda-penanda kesantunan linguistik. Humaniora. 11 (2), 16-23.

Rahardi, K. (2005). Pragmatik: Kesantunan imperatif bahasa Indonesia. Jakarta: Erlangga.

Rahardi, K. 2009. Sosiopragmatik. Jakarta: Erlangga.

Rahmatiah. (2011). Fungsi dan Kesantunan Kalimat Interogatif dalam Tuturan Bahasa makassar. 17(3), 435-444.

Ruytenbeek, N. (2019). Indirect Requests, Relevance, and Politeness. Journal of Pragmatics, 142, 78-89. https://doi.org/10.1016/j.pragma.2019.01.007.

Rica, YDOTK \& Yapılarında KNS. (2015). Politeness strategies used by L2 Turkish speakers in making requests. International Journal of Language Academy. 3 (4), 270-294.

Rizal, K. (2017). Kesantunan Berbahasa Guru dalam Proses Pembelajaran Bahasa Indonesia di SMAN 1 Krembung. Bapala. 4 (1).

Suciu, L. (2014). The Role of Communication in Building the Pedagogical Relationship. Procedia - Social and Behavioral Sciences, 116, 40004004. https://doi.org/10.1016/j.sbspro.2014.01.880

Sudjalil \& Mujianto, G. (2017). Strategi imperatif verbal guru dalam penanaman nilai karakter pada siswa SMA unggulan di Malang. Linguistika. 24 (46), 15-26.

Worotikan, F. (2015). Kalimat imperatif dalam film The Great Gatsby (Suatu analisis sintaksis). Jurnal Elektronik Fakultas Sastra Universitas Sam Ratulangi. 3 (1), 1-15. 